\title{
Expanded home ranges in a peripheral population: space use by endangered Mt. Graham red squirrels
}

\author{
John L. Koprowski*, Sarah R. B. King, Melissa J. Merrick \\ Wildlife Conservation and Management, School of Natural Resources, University of Arizona, Tucson, Arizona 85721, USA
}

\begin{abstract}
Peripheral populations are often of increased conservation value; however, knowledge of the ecological and evolutionary consequences of a peripheral location is poor. Spatial dynamics are often interpreted as strategies to maximize access to fitness-limiting resources. Red squirrels Tamiasciurus hudsonicus are territorial in western portions of their range and exhibit overlapping home ranges in eastern forests. Endangered Mt. Graham red squirrels T. hudsonicus grahamensis represent the southernmost extension of the species. We used radiotelemetry to assess space use and interindividual overlap of endangered Mt. Graham red squirrels. Squirrels maintained nearly exclusive $50 \%$ core areas; however, 95\% ranges overlapped considerably, especially between males and females. Home ranges increased in summer for both males and females and may be related to sexspecific reproductive strategies. Ranges of Mt. Graham red squirrels in this peripheral population were nearly 10 times the size of red squirrels from other locations. The space use of this limital population suggests that resource availability may be substantially different than in other portions of the range.
\end{abstract}

KEY WORDS: Limital population · Geographic range · Tamiasciurus hudsonicus · Arizona · Isolation · Conservation

\section{INTRODUCTION}

Habitat loss and fragmentation are often cited as proximate causes of species loss (Koprowski 2005a). The enhanced conservation value of peripheral populations in fragmented ranges has been championed due to their isolation, genetic variation, and unique adaptations (Lawton 1993, Lesica \& Allendorf 1995, Sullivan 1996, Reese et al. 2001, Vucetich \& Waite 2003, Hampe 2005, Alleaume-Benharira et al. 2006, Antunes et al. 2006). Densities are often greatest near the core of a species' range (Lawton 1993, Vucetich \& Waite 2003), where populations serve as the focus of research from which much of our knowledge of the life history of a species is based (Rushton et al. 2006). Populations at range limits frequently have demographic differences relative to populations at core locations (Lawton 1993, Vucetich \& Waite 2003, Rushton et al. 2006) and substitute species (Caro et al. 2005). Extra- limital populations, or those at the periphery of a species' range, can provide important insights into the limiting factors for a species (Calder 1995); however, these populations may require unique conservation solutions due to differences from core locations.

Spatial dynamics are often viewed as the result of individual strategies to maximize access to resources limiting fitness (Emlen \& Oring 1977, Lott 1991, Boag \& Wiggett 1994, Wolff \& Peterson 1998). Home-range size can vary considerably with changes in distribution of resources and can provide important insights into the relative importance of limiting factors (Ferguson et al. 1999). Home-range size is often predicted to increase with poor resource quality (Dussault et al. 2005) and thus can differ between core and peripheral populations.

Most tree squirrels exhibit overlapping home ranges or defend exclusive core areas to maximize access to mates (Koprowski 1998); however, members of Tamiasciurus spp. are often territorial with resource defense at 
central larderhoards known as middens (Smith 1968, Kemp \& Keith 1970, Rusch \& Reeder 1978, Gurnell 1983, 1987, Koprowski 1998, Steele 1998). Some populations of Tamiasciurus exhibit reduced territoriality with increasing levels of scatterhoarding (Layne 1954, Deutch 1978, Pesce 1982, Hurly \& Robertson 1987).

Mt. Graham red squirrels Tamiasciurus hudsonicus grahamensis are endemic to high elevation Engelmann spruce Picea engelmanni, corkbark fir Abies lasiocarpa var. lasiocarpa and mixed conifer forests in the Pinaleño Mountains of southeastern Arizona, and represent the southernmost extension of a species ranging widely and into arid regions of North America (Brown 1984, Hoffmeister 1986). Ecology of the subspecies is poorly known, despite federally endangered status since 1987 (United States Fish \& Wildlife Service 1993). Knowledge of space use and social organization in this subspecies is restricted to the results of 2 shortterm radiotelemetric studies suggesting that 'territory' size is large (Froehlich 1990, Kreighbaum \& Van Pelt 1996). These results suggest that this peripheral population may use space differently than populations located in the core of the species' range, which provides important insights into the conservation of this critically endangered subspecies. Herein, we examine annual and seasonal spatial dynamics of adult male and female Mt. Graham red squirrels to determine how this subspecies differs in space use relative to other non-imperiled populations of the species in western North America.

\section{MATERIALS AND METHODS}

Study area. We studied Mt. Graham red squirrels in 380 ha of mixed conifer and spruce-fir forest above $3000 \mathrm{~m}$ in the Pinaleño Mountains, Graham County, Arizona, USA, near the Columbine Visitor Center and Mt. Graham International Observatory. The forest is dominated by Engelmann spruce and corkbark fir at highest elevations, with Douglas-fir Pseudotsuga menziesii and Southwestern white pine Pinus strobiformis occurring more frequently as elevation decreases (Hutton et al. 2003). Seasonal weather extremes include heavy winter snowfall from December to April (maximum depth 1992 to 2003: $156.7 \pm 22.7$ (SD) cm, range $=57$ to $285 \mathrm{~cm}$ ) and summer monsoon rains July through September (total accumulation 1996 to 2003: $241.2 \pm 23.9$ (SD) $\mathrm{mm}$, range $=77.8$ to $438.1 \mathrm{~mm}$ ).

Live capture and handling. We trapped Mt. Graham red squirrels at middens from April 2002 to September 2003. Collapsible single door live traps (Tomahawk Live Trap, Tomahawk WI: Model \# 201) baited with peanuts or peanut butter were checked every $2 \mathrm{~h}$ and closed to capture each night. Captured squirrels were transferred to a cloth handling cone (Koprowski 2002) and fitted with uniquely numbered ear tags (Monel 1005-1, National Band and Tag) with colored ear disks (1 cm Model 1842, National Band and Tag) for individual identification. Radiocollars (SOM 2190, Wildlife Materials International) weighing $<5 \%$ of body mass were fitted to restrained animals and replaced as needed (approximate life $=1 \mathrm{yr}$ ). Our field observations of all middens in the study area suggested that $>95 \%$ of squirrels in this area were fitted with a radiocollar. Research was conducted under permit from the University of Arizona's Institutional Animal Care and Use Committee, USDA Forest Service, Arizona Game and Fish Department, and the US Fish and Wildlife Service, Endangered Species Office.

Analyses. We sampled all daylight hours equally from Fall 2002 to Summer 2003 using simultaneous radiotelemetric bearings obtained from $<100 \mathrm{~m}$ of focal squirrels; only interbearing angles $>70^{\circ}$ and $<110^{\circ}$ were used for biangulations. Observer error was tested using the same methods to biangulate on a collar at a known location. Average bearing error was $5.6^{\circ}$ $\left( \pm 4.5^{\circ} \mathrm{SD}\right)$, average distance error was $12 \mathrm{~m}( \pm 6 \mathrm{~m} \mathrm{SD})$, and $\mathrm{n}=62$ biangulations.

We generated point data from telemetry bearing data with LOAS (location of a signal: Ecological Software Solutions) using the best biangulation estimator. Points generated from bearing data were entered into Arcview GIS and combined with data gained from homing. Home-range data were analyzed in Ranges 6 software (Anatrack). We calculated home-range areas using minimum convex polygons (MCPs) and fixed kernel methods and reported both estimates, due to the popularity of each method, thereby facilitating intra- and inter-specific comparisons. Ninety-five percent (termed 'range') and 50\% kernel (termed 'core') home-range estimates were generated and used to assess intra- and intersexual overlap. No core area was apparent when utilization curves were calculated (Wauters et al. 2001), therefore $50 \%$ kernel estimations were used as the core to enable comparison with other studies. Results of overlap analyses for each squirrel using kernel estimates were entered into a matrix to calculate total overlap between all squirrels for 3 dyads (male-male, male-female, female-female). Space use and overlap were examined in relation to seasons of the year, based upon squirrel reproductive and foodstorage behavior (Steele 1998) and plant phenology: fall $=$ September to November; winter $=$ December to February; spring = March to May; summer = June to August. We used the greatest distance from midden center to most distant radiolocation measured in Arcview GIS as the maximum distance moved.

We tested data for normality with KolmogorovSmirnov tests and transformed data as necessary using 
$\ln , \log _{10}+1$ and arcsine root. We conducted 2-way ANOVAs using season and sex or dyad as main effects and included interaction terms in SPSS (version 14.0.0.245: 2005). We compared home-range estimates using Wilcoxon tests.

\section{RESULTS}

\section{Home-range size estimators}

Thirty-three squirrels had > 20 points from Fall 2002 to Summer 2003 (mean $=105.50 \pm 62.1$ [SD] points ind. ${ }^{-1}$ ). Core and range kernels were slightly larger than core and range MCPs (core: Wilcoxon $\mathrm{T}=7.155$, $\mathrm{n}=68, \mathrm{p}<0.0001$, median difference $=0.28$ ha; range: Wilcoxon $\mathrm{T}=2.273, \mathrm{n}=68, \mathrm{p}=0.012$, median difference $=0.086$ ha). The magnitude of difference is relatively small, and both estimators produce similar values and detail identical trends.

\section{Home-range size}

Male core and ranges were similar to females except during summer when cores and ranges were enlarged (Fig. 1). Seasonality, but not sex, had a main effect observed for core and ranges using either the kernel or MCP estimators (Table 1).
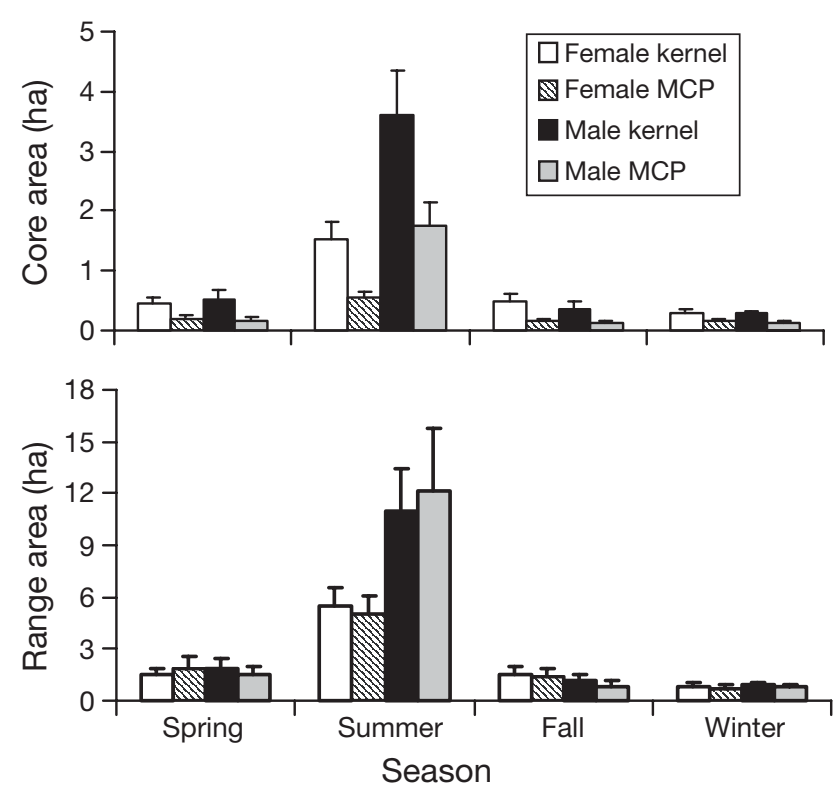

Fig. 1. Tamiasciurus hudsonicus grahamensis. Difference in the mean $( \pm \mathrm{SD}) 50 \%$ core and $95 \%$ home-range areas of male and female Mt. Graham red squirrels in the Pinaleño Mountains, April 2002 to December 2003, across seasons; determined using fixed kernel and minimum convex polygon (MCP) estimators

\section{Distance moved}

The maximum distance from the midden at which a squirrel was located was $923 \mathrm{~m}$ for a male squirrel and $796 \mathrm{~m}$ for a female squirrel. Both males and females were located further from their middens in summer than in any other season (Fig. 2), with no effect of sex evident (Table 1).

\section{Interindividual home-range overlap}

Core and range overlap between female squirrels was minimal during all seasons; however, intermale and intersexual overlap increased markedly during summer at both spatial scales (Fig. 3). Seasons again demonstrated a strong influence on core and range overlap (Table 1), whereas a main effect of sex was also evident for ranges. The complexity of interactions between sex and season is evident from annual patterns of variation where intermale and intersexual dyads vary with season, whereas females lack a seasonal pattern (Fig. 3).

\section{DISCUSSION}

Home ranges in this endangered peripheral population were 3 to 10 times greater than reported for other populations of red squirrels (Zirul \& Fuller 1970, Rusch \& Reeder 1978, Price et al. 1986, Wells 1987, Boutin \& Schweiger 1988, Klenner 1991, Becker et al. 1998). The reason for this striking difference is unclear. Territory size in red squirrels appears to be related to energetic requirements of the territory holder (Smith 1968), suggesting that habitat quality on Mt. Graham is poor compared to other locations. While density can be a misleading indicator of habitat quality (Van Horne 1983), densities on Mt. Graham are among the lowest reported for red squirrels, perhaps due to poor habitat quality (United States Fish \& Wildlife Service 1993). Home-range size in a population of the nearest non-endangered subspecies of red squirrel-Tamiasciurus hudsonicus mogollonensis approximately $110 \mathrm{~km}$ to the north - is significantly smaller than for Mt. Graham red squirrels, despite similar forest characteristics and food availability (Leonard 2006).

The pattern of substantial seasonal changes in home-range size was identical for both male and female Mt. Graham red squirrels, and intersexual overlap in home ranges was considerable, especially during summer. Because sexual dimorphism in body size is minimal in red squirrels (Boutin \& Larsen 1993, Koprowski 2005b), differential metabolic needs 
Table 1. Results of 2-way ANOVAs regarding factors influencing the space use by Mt. Graham red squirrels Tamiasciurus hudsonicus grahamensis. Probability values (p) are in bold for significant $(p<0.05)$ effects. MCP: minimum convex polygon

\begin{tabular}{|c|c|c|c|}
\hline Dependent variable and factors & df & F & $\mathrm{p}$ \\
\hline Kernel $50 \%$ core area & \multicolumn{3}{|c|}{$\left(\mathrm{n}=69, \mathrm{R}^{2}=0.444\right)$} \\
\hline Sex & 1,60 & 0.934 & 0.338 \\
\hline Season & 3,60 & 18.726 & 0.001 \\
\hline Sex $\times$ Season & 3,60 & 1.125 & 0.346 \\
\hline Kernel 95\% range area & \multicolumn{3}{|c|}{$\left(\mathrm{n}=70, \mathrm{R}^{2}=0.378\right)$} \\
\hline Sex & 1,60 & 1.156 & 0.287 \\
\hline Season & 3,60 & 14.672 & 0.001 \\
\hline Sex $\times$ Season & 3,60 & 0.872 & 0.461 \\
\hline MCP $50 \%$ core area & \multicolumn{3}{|c|}{$\left(\mathrm{n}=66, \mathrm{R}^{2}=0.395\right)$} \\
\hline Sex & 1,56 & 0.851 & 0.360 \\
\hline Season & 3,56 & 15.329 & 0.001 \\
\hline Sex $\times$ Season & 3,56 & 1.039 & 0.382 \\
\hline MCP $95 \%$ range area & \multicolumn{3}{|c|}{$\left(\mathrm{n}=70, \mathrm{R}^{2}=0.380\right)$} \\
\hline Sex & 1,60 & 0.608 & 0.439 \\
\hline Season & 3,60 & 15.255 & 0.001 \\
\hline Sex $\times$ Season & 3,60 & 0.863 & 0.465 \\
\hline Maximum distance moved & \multicolumn{3}{|c|}{$\left(\mathrm{n}=70, \mathrm{R}^{2}=0.383\right)$} \\
\hline Sex & 1,60 & 2.514 & 0.118 \\
\hline Season & 3,60 & 14.939 & 0.001 \\
\hline Sex $\times$ Season & 3,60 & 0.788 & 0.505 \\
\hline Overlap of kernel $50 \%$ core area & \multicolumn{3}{|c|}{$\left(\mathrm{n}=140, \mathrm{R}^{2}=0.480\right)$} \\
\hline Dyad & 2,126 & 0.830 & 0.438 \\
\hline Season & 3,126 & 31.523 & 0.001 \\
\hline Dyad $\times$ Season & 6,126 & 4.770 & 0.001 \\
\hline \multicolumn{4}{|c|}{ Overlap of kernel $95 \%$ core area $\quad\left(n=140, R^{2}=0.594\right)$} \\
\hline Dyad & 2,126 & 5.115 & 0.007 \\
\hline Season & 3,126 & 45.135 & 0.001 \\
\hline Dyad $\times$ Season & 6,126 & 8.185 & 0.001 \\
\hline
\end{tabular}

do not likely explain the sex difference in overlap. Differential increases occur at a time of year when females are most likely to enter into estrus (Lair 1985, Koprowski 2005b), suggesting that home range

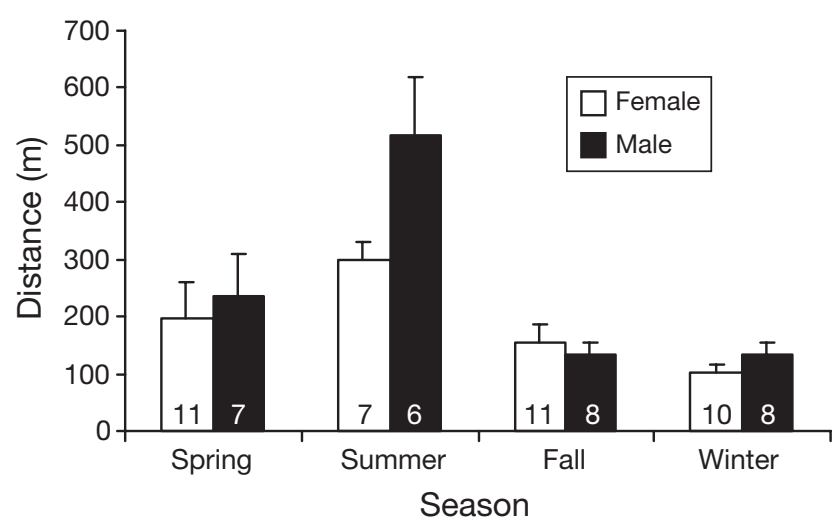

Fig. 2. Tamiasciurus hudsonicus grahamensis. Mean $( \pm \mathrm{SE})$ of the maximum distance moved $(\mathrm{m})$ by Mt. Graham red squirrels from the midden, April 2002 to December 2003. Sample size is given at the base of each bar expansion is, in part, influenced by availability of mates. Female tree squirrels are in estrus for $<1 \mathrm{~d}$ during a breeding season of 2 to 4 mo. As a result, females are relatively asynchronous, and males appear to monitor reproductive status by olfaction (Lair 1985, Gurnell 1987, Arbetan 1992, Becker 1993, Koprowski 1993a,b, Steele \& Koprowski 2001). As many as 34 males (Goodrum 1961) can be attracted to a female from $\leq 500 \mathrm{~m}$ about $5 \mathrm{~d}$ before estrus (Thompson 1977), and the immediate operational sex ratio (Dearborn et al. 2001) is heavily male biased with intense mate competition. Seasonal increases of such magnitude in home range for both sexes have not been previously reported for red squirrels. Home ranges of male tree squirrels Sciurus, however, are often larger during breeding seasons, due to mate searching (Koprowski 1998).

Home ranges may be constrained through most of the year by a paucity of food that has a clumped distribution. During fall, winter and spring, squirrels need to invest energy in defending larderhoards at middens (Gurnell 1984), and food supplies are concentrated at cone-bearing trees and the midden. In summer, cached food stocks are depleted and new, widely dispersed, food sources such as mushrooms and ripening cones become available (Ferron et al. 1985). This may explain the increase in female range during summer and, in conjunction with mate searching, may account for the large summer home ranges as males greatly expand home ranges.

Differential overlap between the sexes through the year provides further evidence for the influential role of food and mate resources on spatial dynamics (Emlen \& Oring 1977, Lott 1991, Boag \& Wiggett 1994, Wolff \& Peterson 1998). Territoriality is the most common social system of red squirrels (Smith 1968, Davis 1969, Kemp \& Keith 1970, Rusch \& Reeder 1978, Gurnell 1983, Boutin \& Schweiger 1988, Koprowski 1998). Male Mt. Graham red squirrels had discrete cores in all seasons except for summer, when males traveled widely with considerable interindividual overlap likely to locate scarce females. Female Mt. Graham red squirrels minimized overlap during all seasons including summer despite an overall increase in summer ranges; thus, intrasexual territoriality was retained throughout the year as observed in Eurasian red squirrels Sciurus vulgaris (Wauters \& Dhondt 1992, Wauters et al. 2001). These results support a view of social systems as variable within a species in response to environmental factors (Lott 1991). Seasonal and sex-specific reduction in territoriality emphasizes the need to understand sex-specific strategies more fully in conservation (Koprowski 1998).

The large home ranges, reduced territoriality, and considerable distances traversed by Mt. Graham red 


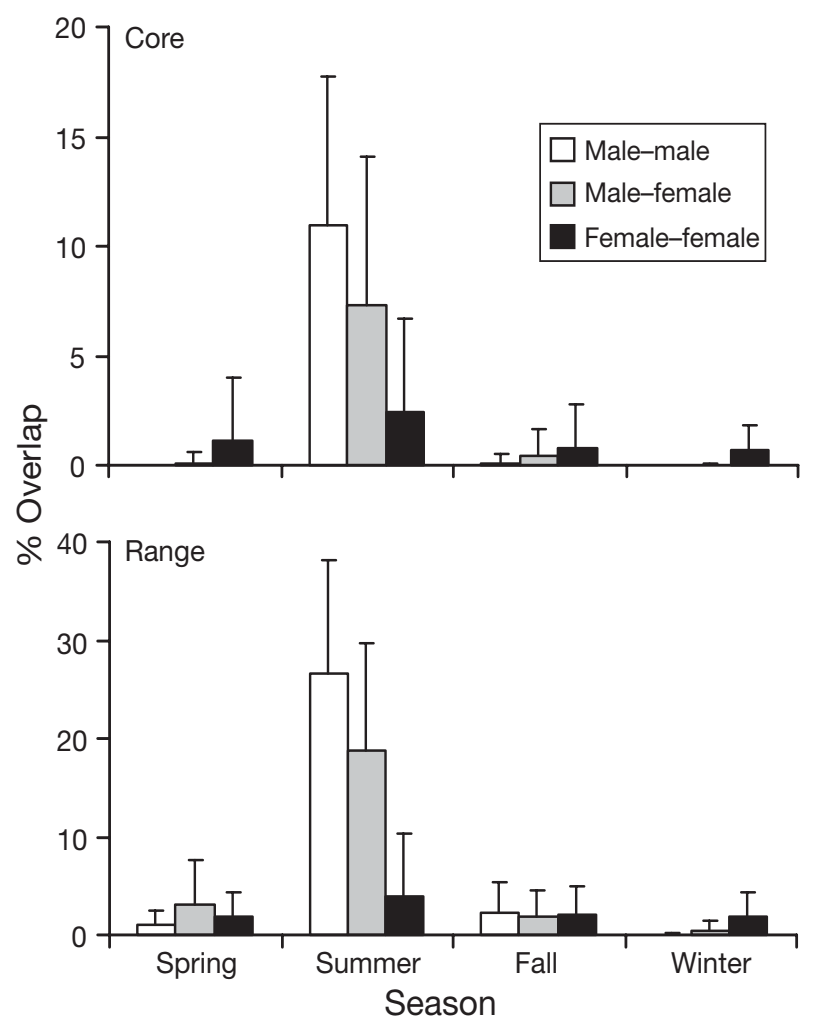

Fig. 3. Tamiasciurus hudsonicus grahamensis. Mean $( \pm \mathrm{SD})$ percent overlap of male and female Mt. Graham red squirrel $50 \%$ core and $95 \%$ home-range areas in the Pinaleño Mountains, April 2002 to December 2003

squirrels must be considered in the scale of conservation strategies developed for this endangered subspecies. In addition, this study indicates that space use is another biological metric that may differ between core and peripheral populations, creating challenges to their conservation. Such unpredictable results in peripheral populations (Lawton 1993, Vucetich \& Waite 2003, Rushton et al. 2006) that may require reevaluation of the spatial scale of conservation efforts underscore the need for detailed study of endangered species, rather than solely relying on comparative data from substitute species (Caro et al. 2005) or core populations.

Acknowledgements. We thank M. Alanen, S. Bertelsen, K. Dickinson, A. Edelman, E. Freels, V. Greer, L. Habib, K. Hutton, K. Leonard, K. Munroe, M. Griffiths, E. Pettitt, C. Schauffert, V. Steen, C. Steimer, M. Yurenka, and C. Zugmeyer for assistance with live trapping and telemetry. S. Bertelsen, N. Ramos, V. Greer, and 3 anonymous reviewers provided helpful comments on drafts of the manuscript. Funding and in kind support were provided by Arizona Game and Fish Department, USDA Forest Service, The University of Arizona's Office of the Vice President for Research, Steward Observatory, and the Arizona Agricultural Experiment Station.

\section{LITERATURE CITED}

Alleaume-Benharira M, Pen IR, Ronce O (2006) Geographic patterns of adaptation within a species' range: interactions between drift and gene flow. J Evol Biol 19:203-215

Antunes A, Faria R, Johnson WE, Guyomard R, Alexandrino P (2006) Life on the edge: the long-term persistence and contrasting spatial genetic structure of distinct brown trout life histories at their ecological limits. J Hered 97: 193-205

Arbetan PT (1992) The mating system of the red squirrel (Tamiasciurus hudsonicus). PhD thesis, University of Kansas, Lawrence, KS

Becker CD (1993) Environmental cues of estrus in the North American red squirrel (Tamiasciurus hudsonicus Bangs). Can J Zool 71:1326-1333

Becker CD, Boutin S, Larsen KW (1998) Constraints on first reproduction in North American red squirrels. Oikos 81: $81-92$

Boag DA, Wiggett DR (1994) Food and space resources defended by territorial parous female Columbian ground squirrels. Can J Zool 72:1908-1914

Boutin S, Larsen KW (1993) Does food availability affect growth and survival of males and females differently in a promiscuous small mammal, Tamiasciurus hudsonicus? J Anim Ecol 62:364-370

Boutin S, Schweiger S (1988) Manipulation of intruder pressure in red squirrels (Tamiasciurus hudsonicus): effects on territory size and acquisition. Can J Zool 66:2270-2274

Brown DE (1984) Arizona's tree squirrels. Arizona Game and Fish Department, Phoenix, AZ

Calder WA (1995) An extralimital broad-tailed hummingbird in winter: disoriented or harbinger of change? J Field Ornithol 66:522-530

Caro T, Eadie J, Sih A (2005) Use of substitute species in conservation biology. Conserv Biol 19:1821-1826

Davis DW (1969) The behavior and population dynamics of the red squirrel (Tamiasciurus hudsonicus) in Saskatchewan. PhD thesis, University of Arkansas, Fayetteville, AR

Dearborn DC, Anders AD, Parker PG (2001) Sexual dimorphism, extrapair fertilizations, and operational sex ratio in great frigatebirds (Fregata minor). Behav Ecol 12:746-752

Deutch RS (1978) Seasonal activity budget of the red squirrel (Tamiasciurus hudsonicus) in southern Ohio. MS thesis, University of Dayton, Dayton, $\mathrm{OH}$

Dussault C, Courtois R, Ouellet JP, Girard I (2005) Space use of moose in relation to food availability. Can J Zool 83: $1431-1437$

Emlen ST, Oring LW (1977) Ecology, sexual selection and the evolution of mating systems. Science 197:215-223

Ferron J, Ouellet JP, Lemay Y (1985) Spring and summer time budgets and feeding behavior of the red squirrel (Tamiasciurus hudsonicus). Can J Zool 64:385-391

Froehlich GF (1990) Habitat use and life history of the Mt. Graham red squirrel. MS thesis, University of Arizona, Tucson, AZ

Ferguson SH, Taylor MK, Born EW, Rosing-Asvid A, Messier F (1999) Determinants of home range size for polar bears (Ursus maritimus). Ecol Lett 2:311-318

Goodrum PD (1961) The gray squirrel in Texas. Tex Parks Wildl Dep Bull 42:1-43

Gurnell J (1983) Squirrel numbers and the abundance of tree seeds. Mamm Rev 13:133-148

Gurnell J (1984) Home range, territoriality, caching behaviour and food supply of the red squirrel (Tamiasciurus hudsonicus fremonti) in a subalpine lodgepole pine forest. Anim 
Behav 32:1119-1131

Gurnell JC (1987) The natural history of squirrels. Facts on File, New York

Hampe A (2005) Fecundity limits in Frangula alnus (Rhamnaceae) relict populations at the species' southern range margin. Oecologia 143:377-38

Hoffmeister DF (1986) Mammals of Arizona. University of Arizona Press, Tucson, AZ

Hurly TA, Robertson RJ (1987) Scatterhoarding by territorial red squirrels: a test of the optimal density model. Can J Zool 65:1247-1252

Hutton KA, Koprowski JL, Greer VL, Alanen MI, Schauffert CA, Young PJ (2003) Use of mixed conifer and spruce-fir forests by an introduced population of Abert's squirrels (Sciurus aberti). Southwest Nat 48:257-260

Kemp GA, Keith LB (1970) Dynamics and regulation of red squirrel (Tamiasciurus hudsonicus) populations. Ecology 51:763-779

Klenner W (1991) Red squirrel population dynamics II. Settlement patterns and the response to removals. J Anim Ecol 60:979-993

Koprowski JL (1993a) Alternative reproductive tactics in male eastern gray squirrels: 'making the best of a bad job'. Behav Ecol 4:165-171

Koprowski JL (1993b) Behavioral tactics, dominance, and copulatory success among male fox squirrels. Ethol Ecol Evol 5:169-176

Koprowski JL (1998) Conflict between the sexes: a review of social and mating systems of the tree squirrels. In: Steele MA, Merritt JF, Zegers DA (eds) Ecology and evolutionary biology of tree squirrels. Virginia Museum of Natural History, Martinsville, VA, p 33-41

Koprowski JL (2002) Handling tree squirrels with a safe and efficient restraint. Wildl Soc Bull 30:101-103

Koprowski JL (2005a) The response of tree squirrels to fragmentation: a review and synthesis. Anim Conserv 8: 369-376

Koprowski JL (2005b) Annual cycles in body mass and reproduction in the endangered Mt. Graham red squirrel, a montane island endemic. J Mammal 86:309-313

Kreighbaum ME, Van Pelt WE (1996) Mount Graham red squirrel juvenile dispersal telemetry study. Nongame and Endangered Wildlife Program Technical Report 89, Arizona Game and Fish Department, Phoenix, AZ

Lair H (1985) Length of gestation in the red squirrel (Tamiasciurus hudsonicus). J Mammal 66:809-810

Lawton JH (1993) Range, population abundance, and conservation. Trends Ecol Evol 8:409-413

Layne JN (1954) The biology of the red squirrel, Tamiasciurus hudsonicus loquax (Bangs), in central New York. Ecol Monogr 24:227-267

Leonard KM (2006) Variation among red squirrel populations: ecological differences at the edge of their range and response to fire. MS thesis, University of Arizona, Tucson, $\mathrm{AZ}$

Lesica P, Allendorf FW (1995) When are peripheral popula-

Editorial responsibility: Brendan Godley (Editor-in-Chief),

University of Exeter, Cornwall Campus, UK tions valuable for conservation? Conserv Biol 9:753-760

Lott DF (1991) Intraspecific variation in the social systems of wild vertebrates. University of Cambridge Press, New York

Pesce A (1982) Dynamics of a non-terrtorial population of red squirrel (Tamiasciurus) in southeastern Michigan. MS thesis, University of Michigan, Ann Arbor, MI

Price K, Broughton K, Boutin S, Sinclair ARE (1986) Territory size and ownership in red squirrels: response to removals. Can J Zool 64:1144-1147

Reese CL, Waters JM, Pagels JF, Brown BL (2001) Genetic structuring of relict populations of Gapper's red-backed vole (Clethrionomys gapperi). J Mammal 82:289-301

Rusch DA, Reeder WG (1978) Population ecology of Alberta red squirrels. Ecology 59:400-420

Rushton SP, Wood DJA, Lurz PWW, Koprowski JL (2006) Modelling the population dynamics of the Mt. Graham red squirrel: can we predict its future in a changing environment with multiple threats? Biol Conserv 131:121-131

Smith CC (1968) The adaptive nature of social organization in the genus ofthree squirrels Tamiasciurus. Ecol Monogr 38: $31-63$

Steele MA (1998) Tamiasciurus hudsonicus. Mamm Species 586:1-9

Steele MA, Koprowski JL (2001) North American tree squirrels. Smithsonian Institution Press, Washington, DC

Sullivan RM (1996) Genetics, ecology, and conservation of montane populations of Colorado chipmunks (Tamias quadrivittatus). J Mammal 77:951-975

Thompson DC (1977) Reproductive behaviour of the grey squirrel. Can J Zool 55:1176-1184

United States Fish \& Wildlife Service (1993) Mount Graham red squirrel recovery plan. United States Fish and Wildlife Service, Albuquerque, NM

Van Horne B (1983) Density as a misleading indicator of habitat quality. J Wildl Manag 47:893-901

Vucetich JA, Waite TA (2003) Spatial patterns of demography and genetic processes across the species' range: null hypotheses for landscape conservation genetics. Conserv Genet 4:639-645

Wauters L, Dhondt AA (1992) Spacing behavior of red squirrel, Sciurus vulgaris: variation between habitats and the sexes. Anim Behav 43:297-311

Wauters LA, Gurnell J, Preatoni D, Tosi G (2001) Effects of spatial variation in food ability on spacing behavior and demography of Eurasian red squirrels. Ecography 24: $525-538$

Wells NM (1987) The dynamics of space use in a red squirrel (Tamiasciurus hudsonicus) population. PhD thesis, University of Michigan, Ann Arbor, MI

Wolff JO, Peterson JA (1998) An offspring-defense hypothesis for territoriality in female mammals. Ethol Ecol Evol 10: 227-239

Zirul DL, Fuller WA (1970) Winter fluctuations in size of home range of the red squirrel, Tamiasciurus hudsonicus. Trans N Am Wildl Nat Res Conf 35:115-127

Submitted: February 16, 2007; Accepted: April 12, 2007

Proofs received from author(s): June 14, 2007 